\title{
Assessment of global motor performance and gross and fine motor skills of infants attending day care centers
}

\author{
Avaliação do desempenho motor global e em habilidades motoras axiais e \\ apendiculares de lactentes frequentadores de creche
}

Carolina T. Souza', Denise C. C. Santos', Rute E. Tolocka², Letícia Baltieri³, Nathália C. Gibim³, Fernanda A. P. Habechian ${ }^{3}$

\begin{abstract}
Objective: To analyze the global motor performance and the gross and fine motor skills of infants attending two public child care centers full-time. Methods: This was a longitudinal study that included 30 infants assessed at 12 and 17 months of age with the Motor Scale of the Bayley Scales of Infant and Toddler Development, Third Edition (Bayley-III). This scale allows the analysis of global motor performance, fine and gross motor performance, and the discrepancy between them. The Wilcoxon test and Spearman's correlation coefficient were used. Results: Most of the participants showed global motor performance within the normal range, but below the reference mean at 12 and 17 months, with 30\% classified as having "suspected delays" in at least one of the assessments. Gross motor development was poorer than fine motor development at 12 and at 17 months of age, with great discrepancy between these two subtests in the second assessment. A clear individual variability was observed in fine motor skills, with weak linear correlation between the first and the second assessment of this subtest. A lower individual variability was found in the gross motor skills and global motor performance with positive moderate correlation between assessments. Considering both performance measurements obtained at 12 and 17 months of age, four infants were identified as having a "possible delay in motor development". Conclusions: The study showed the need for closer attention to the motor development of children who attend day care centers during the first 17 months of life, with special attention to gross motor skills (which are considered an integral part of the child's overall development) and to children with suspected delays in two consecutive assessments.
\end{abstract}

Key words: day care centers; infant; child development.

\section{Resumo}

Objetivo: Analisar o desempenho motor global em habilidades motoras axiais e apendiculares de lactentes que frequentavam, em tempo integral, duas Escolas Municipais de Educação Infantil. Métodos: Estudo longitudinal do qual participaram 30 lactentes avaliados aos 12 e 17 meses de vida com a escala motora das Bayley Scales of Infant and Toddler Development-III, que possibilita a análise do desempenho motor global, apendicular e axial e a discrepância entre eles. Utilizaram-se o teste de Wilcoxon e o Coeficiente de Correlação de Spearman. Resultados: A maioria dos participantes apresentou desempenho motor global dentro dos limites de normalidade, porém abaixo da média de referência aos 12 e 17 meses, com 30\% classificados como suspeitos de atraso em pelo menos uma das avaliações. O desempenho motor axial foi inferior ao apendicular aos 12 e aos 17 meses, com grande discrepância entre eles especialmente na $2^{a}$ avaliação. Observou-se marcada variabilidade individual nas habilidades motoras apendiculares, com fraca correlação linear no desempenho entre a $1^{a}$ e a $2^{a}$ avaliações nesse domínio. Nas habilidades axiais e no desempenho motor global, encontrou-se menor variabilidade individual, com correlações moderadas e positivas entre a $1^{\mathrm{a}}$ e a $2^{\mathrm{a}}$ avaliações. Identificaram-se quatro lactentes com suspeita de atraso no desenvolvimento motor em ambas as avaliações. Conclusões: O estudo aponta necessidade de maior atenção ao desenvolvimento motor durante os primeiros 17 meses de crianças que frequentam creches, com especial vigilância à motricidade axial (considerando que ela é parte integrante do desenvolvimento global da criança) e às crianças com desempenho suspeito de atraso em duas avaliações consecutivas.

Palavras-chave: creches; lactente; desenvolvimento infantil.

Received: 27/02/2009 - Revised: 24/08/2009 - Accepted: 21/10/2009

\footnotetext{
Graduate Program in Physical Therapy, Faculdade de Ciências da Saúde (FACIS), Universidade Metodista de Piracicaba (UNIMEP), Piracicaba (SP), Brazil

2 Graduate Program in Physical Education, FACIS, UNIMEP

${ }^{3}$ Physical Therapy Course, FACIS, UNIMEP

Correspondence to: Denise Castilho Cabrera Santos, Universidade Metodista de Piracicaba, Rodovia do Açúcar, Km 156 - Taquaral, CEP 13400-911, Piracicaba (SP), Brazil,

e-mail: dcsantose@unimep.br
} 


\section{Introduction : :}

References to child day care centers worldwide are unanimous in stating that these centers were created to provide care to infants whose mothers began to work outside the home. This change in the style of rearing and educating children started during the Industrial Revolution in 18th-century Europe and spread throughout the Western world. Until today, the women-work-children triad is responsible for a large part of the demand for placement in day care centers or early childhood education centers ${ }^{1}$.

In several parts of the world, researchers and governments have become concerned with non-maternal care and its repercussions for children's development, combined with the inclusion of infants in collective care institutions or day care centers. In the United States, this concern increased in the 1980s, when studies first began to report undesirable results in child behavior and in mother-child relationships related to day care center attendance ${ }^{2}$. These findings, combined with the growing reality of American children attending day care centers, were the driving force behind the largest study conducted up to that point on the impact that this scenario can have on child development, the Study of Early Child Care (SECC) by the National Institute of Child Health and Human Development. From 1991, more than 1200 infants had longitudinal follow-up from birth until adolescence. The results of the SECC highlight that exposure to quality day care is predictive of functional advance in cognitive and language areas. In contrast, in the first four years of life, a higher exposure (in hours) to day care environments, even quality ones, is related to high levels of behavioral problems ${ }^{2}$. Similar results were observed in another wide study performed in England, known as the EPPE Study (Early Effective Provision of Preschool Education), which followed up 3000 infants $^{3}$.

The international literature shows significant concern for the impact of long hours of day care on increasingly younger children in terms of cognitive, linguistic, social, emotional, and behavioral development ${ }^{2-4}$. Nevertheless, foreign studies in particular do not include motor development as an aspect to be investigated. In Brazil, however, there has been increasing concern with this model of care and its repercussions for children's motor development, possibly due to the number of studies that point to issues related to the professionals' qualification, infrastructure, strict routines focused mainly on feeding and hygiene, and greater exposure to infectious processes ${ }^{5-8}$.

Santos et $\mathrm{al}^{9}$ pointed out that, in Brazil, several studies have reported suspected delays in development, including motricity; however, the results are inconclusive because the prevalence of delays or suspected delays is very heterogeneous among the studies, ranging from $10 \%$ to $43 \%^{10-15}$. Other prominent aspects in the literature are the common discrepancies or differences in performance between the gross and fine motor subtests ${ }^{11,13,15,16}$, in addition to reports that the learning environment does not always promote infant motor development ${ }^{17,18}$. The Brazilian studies reviewed in this article pointed to delays or suspected delays in motor development, however they did not analyze the process of this development in infants that attend day care centers, and the majority of studies performed only one developmental assessment (cross-sectional design). It is accepted that only longitudinal studies allow the comprehension of the emergence pattern of developmental functions ${ }^{19}$ and the identification of the inconsistent, non-linear nature of child development ${ }^{20}$.

In this context, the present study aimed to analyze the overall motor development and the gross and fine motor skills of infants enrolled full time in two public child care centers in the city of Piracicaba, SP, Brazil. The infants were assessed longitudinally at 12 and 17 months of age. The specific objectives of the study were: (a) to analyze the global motor performance and compare gross and fine motor skills at 12 and 17 months of age to identify discrepancies between them; (b) to analyze the process of overall, gross and fine development from the $12^{\text {th }}$ to the $17^{\text {th }}$ month of age; (c) to identify infants with suspected delays in motor development considering the two assessments of overall motor development.

\section{Methods::}

This was a descriptive and longitudinal study that assessed 30 infants (50\% female) attending two public day care centers of Piracicaba, SP, Brazil. Their overall motor development and gross and fine motor skills were assessed at $12 \pm 0.61$ months ( $1^{\text {st }}$ assessment) and $17 \pm 0.33$ months ( $2^{\text {nd }}$ assessment). The present study was approved by the Research Ethics Committee of Universidade Metodista de Piracicaba, Piracicaba (SP), Brazil (protocol no. 61/06).

The participating day care centers were recommended by the city's Education Secretary, considering the interest expressed by the local managers and the regional supervisors in taking part in this project and because they did not have any physical therapy, physical education or other intervention activities. In order to select the study group, the following inclusion criteria were considered: a) full-time attendance at day care center; b) chronological age or corrected age for preterm infants between 11 and 13 months ( $1^{\text {st }}$ assessment) and 17-18 months ( $2^{\text {nd }}$ assessment); c) informed consent form signed by the family. Children with neurological disorders, genetic syndromes or malformation were excluded. To assess motor development, we used the Motor Scale of the Bayley Scales of 
Infant and Toddler Development, Third Edition (Bayley-III) ${ }^{21}$, which allows the analysis of overall, gross, and fine motor development, in addition to the analysis of possible discrepancies between the last two. The performance in the gross and fine subtests was expressed through a standard score that ranges from 1 to 19 points, with a reference mean of $10 \pm 3$. The global motor performance is the result of the gross and fine performances and is expressed through a standardized score that ranges from 40 to 160 points, with a reference mean of $100 \pm 15$. Considering the possible variations above or below the reference mean, the scale recommends that the overall motor development be classified as high superior (score equal to or above 130 points), superior (120-129 points), high average (110-119 points), average (90-109 points), low average (80-89 points), borderline (70-79 points) and extremely low (score equal to or below 69). In the present study, the cutoff score established for the classification of suspected delay in global motor performance was a score below 90. In other words, the children considered to have suspected delays were those with a performance classified as low average, borderline or extremely low.

Each child was assessed by two raters considering the chronological age or corrected age for preterm infants. One rater was responsible for the test application, and the other for recording the results. The raters received Bayley-III training and took part in a reliability study including 15 infants assessed independently by each rater. The inter-rater correlation coefficient and the corresponding confidence interval (95\%) for the fine, gross and global motor performances were 0.98 (0.950.99), 0.99 (0.98-0.99), and 0.99 (0.98-0.99), respectively. For the assessment sessions, we used a mat, a table and chair, and the original Bayley-III kit. The assessed child had to be alert and should not be wearing clothing that could restrain movement. The test was scheduled around the day care center's feeding, bathing and nap times.

Data were stored and processed using the Statistical Package for Social Sciences (version 11.0). For the normality analysis, the Shapiro-Wilk test was used for the gross $(p=0.019)$, fine $(p=0.002)$ and overall $(p=0.792)$ motor performances. Considering that only the global motor performance showed a normal distribution, non-parametric data analysis was used. The group characterization was performed through descriptive analysis. The continuous variables were expressed by measures of central tendency and dispersion, and the categorical variables by frequencies. The Wilcoxon test was used for the analysis of the paired data, Spearman's rank correlation coefficient (r) was used for the correlation analysis, and the scatter plot was analyzed. The level of significance set in the present study was of $5 \%$.

\section{Results $: \because$.}

The study included 30 infants, of whom four (13.8\%) were born preterm (less than 37 weeks) and two (7\%) were born with low birth weight (below 2500 grams). With regard to Apgar scores, the lowest score was eight at the $1^{\text {st }}$ minute of life. None of the infants showed clinical complications at birth. Participants attended two public day care centers full time. At these centers, the child:staff ratio was 7:1 in the studied age groups, with 14 children per room.

Considering the classification recommended by the scale, most participants showed global motor performance within normal range (above 80 ) but below the reference mean (100) at 12 months (median $=97$, minimum $=70$, maximum $=121$ ) and 17 months $($ median $=98$, minimum $=79$, maximum $=124$ ) with nine (30\%) participants classified as having suspected delays, according to the cutoff score adopted for the study (low average performance or borderline) in at least one of the assessments (Figure 1A). More specifically, four infants were classified as having suspected delays only in the $1^{\text {st }}$ assessment, four in the $1^{\text {st }}$ and $2^{\text {nd }}$ assessments and only one in the $2^{\text {nd }}$ assessment. In both assessments, none of the children had an extremely low performance (score $\leq 69$ ).

The comparison of the performances in the gross and fine motor subtests (Wilcoxon test) showed significant differences, with poorer gross performance both in the $1^{\text {st }}$ assessment at 12 months $(\mathrm{p}=0.008)$ and in the $2^{\text {nd }}$ assessment at 17 months $(p<0.001)$ with great discrepancy between them, especially in the $2^{\text {nd }}$ assessment, in which $63.3 \%$ of the infants showed significant difference between the gross and fine subtests (Figure 1B).

The trajectory of overall, fine and gross motor development between the $1^{\text {st }}$ and $2^{\text {nd }}$ assessments was analyzed using Spearman's correlation coefficient and scatter plots (Figure 2). The first scatter plot (Figure 2A) showed a significant variability in individual performances between the $1^{\text {st }}$ and $2^{\text {nd }}$ assessments of fine motor skills and a weak correlation in this area $(r=0.291, p=0.119)$. There was less variability in gross motor skills and in global motor performance, as indicated by the moderate and positive linear correlations between $1^{\text {st }}$ and $2^{\text {nd }}$ assessments in the gross motor subtest $(\mathrm{r}=0.616, \mathrm{p}<0.001)$ and in overall performance $(\mathrm{r}=0.543$, $\mathrm{p}=0.02$; Figures $2 \mathrm{~B}$ and $2 \mathrm{C}$ ).

In the $1^{\text {st }}$ assessment, 22 infants were classified as having adequate performance and eight as having suspected delays. Of the 22 infants with adequate performance in the $1^{\text {st }}$ assessment, only one was classified as having a suspected delay in the $2^{\text {nd }}$ assessment. In contrast, of the eight infants with suspected delays in the $1^{\text {st }}$ assessment, four had suspected delays 


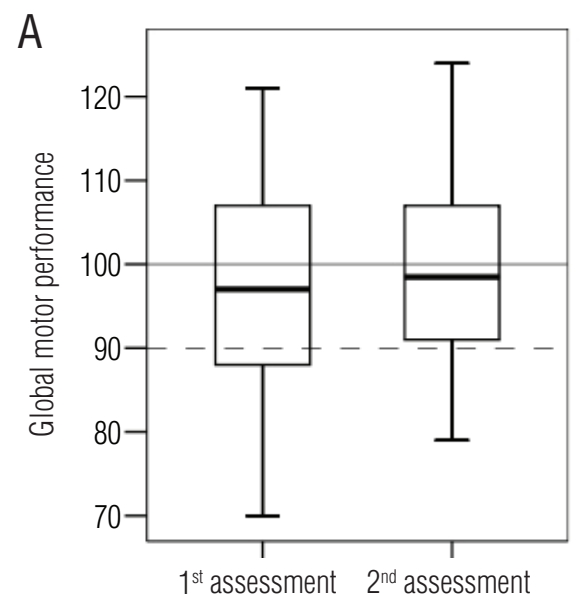

B

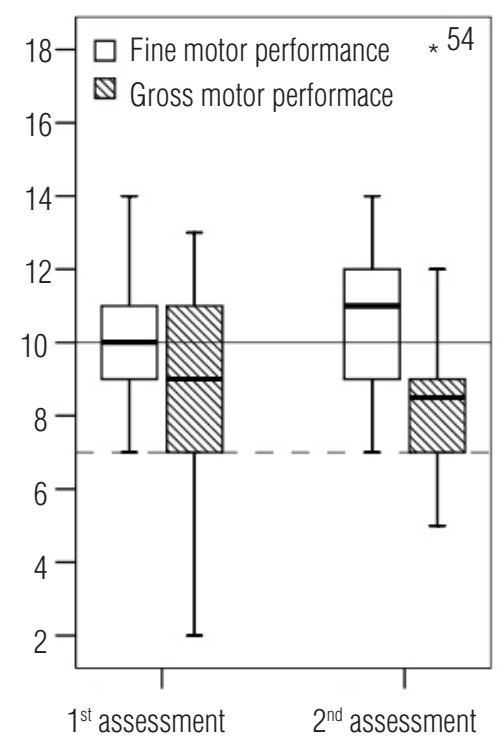

A) Global motor performance. B) Fine and gross motor performance. Continuous line (average reference). Dashed line highlights the cutoff score for the classification of suspected delay.

Figure 1. Motor performance on $1^{\text {st }}$ and $2^{\text {nd }}$ assessments.

in the $2^{\text {nd }}$ assessment, while the others showed adequate motor performance. Thus, of the 30 infants followed up in the present study, four (13\%) had suspected delays in overall performance (scores below 90) in both assessments. Of these, only one was born preterm (32 weeks gestation) and with low birth weight (1670g). The others were born at term weighing over 2500 grams.

\section{Discussion $: \because$.}

In the present study, although most participants presented global motor performance within normal range, $30 \%$ were

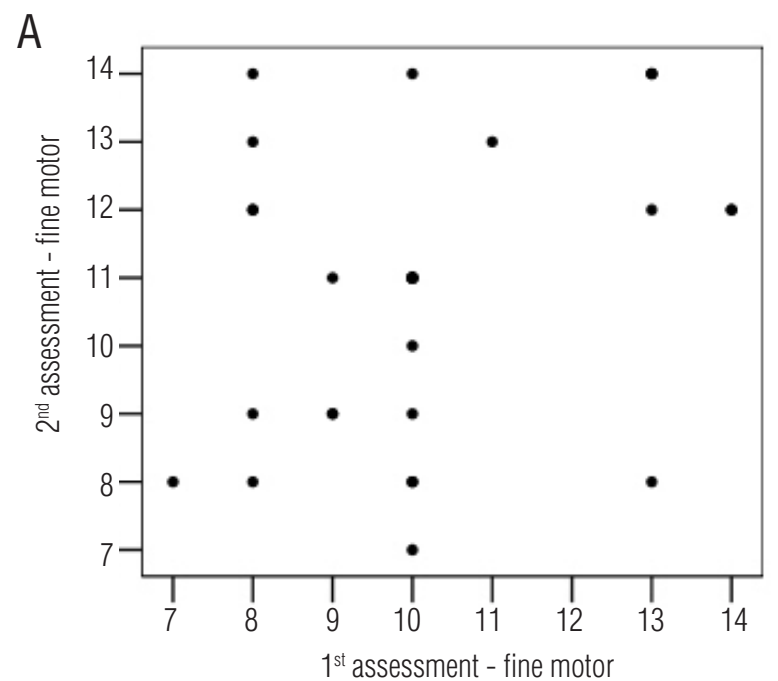

B

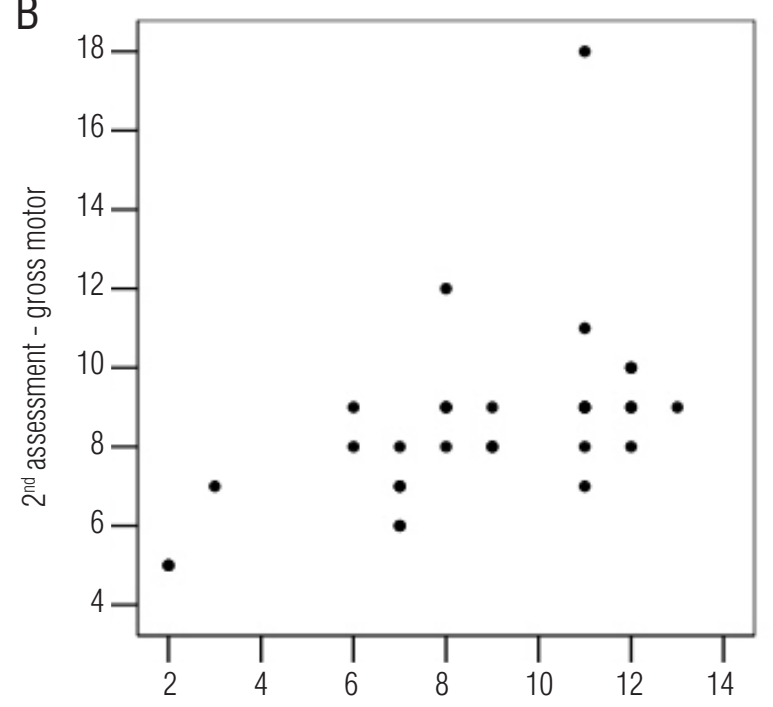

C

$1^{\text {st }}$ assessment - gross motor

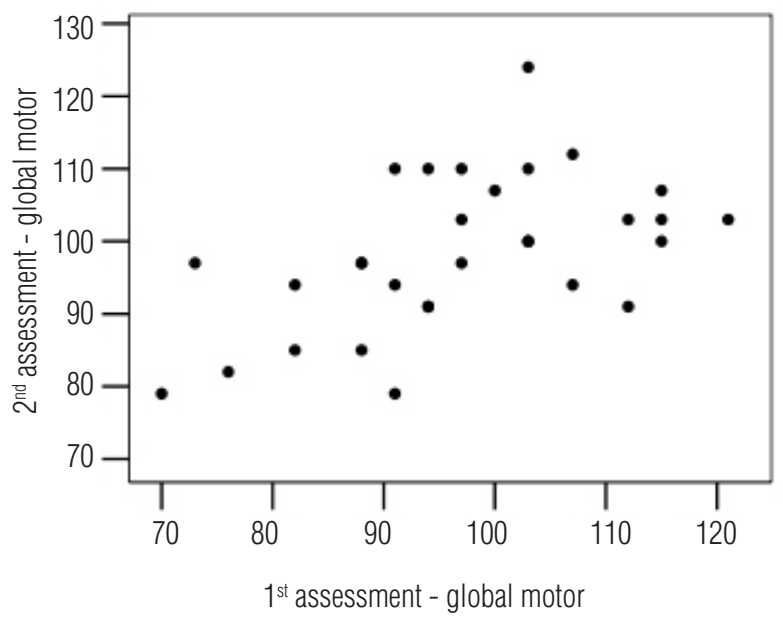

A) Fine motor performance $(r=0.291 ; p=0.119)$. B) Gross motor performance $(r=0.616 ; p<0.001)$. C) Global motor performance $(r=0.543 ; p=0.02)$.

Figure 2. Scatter plot. 
classified as having suspected delays in global motor performance in at least one of the assessments. The gross motor performance was poorer than the fine motor performance at 12 and 17 months of life, and there was great discrepancy between them, especially in the $2^{\text {nd }}$ assessment. Corroborating the findings of the present study, the reviewed literature indicates frequent cases of suspected or actual developmental delays among children attending day care centers. In general, these studies indicate the multiplicity of possible factors affecting motor development, including biological hazards (i.e. low birth weight, preterm birth), unfavorable socioeconomic conditions, poor parental education, multiple stress situations, and poor stimulation, often due to the day care environment ${ }^{10,12,14,22}$.

Also supporting the findings of the present study, the reviewed literature highlights frequent situations of discrepancy or difference between gross and fine motor performances, with better fine motor performance in some instances and better gross motor performance in others ${ }^{11,13,15,16}$. In addition to the disadvantage in gross motor skills compared to fine motor skills, the present study showed greater individual variability in the trajectory of fine motor performance compared to the gross and global motor performances, e.g. the poorest performance (gross) also showed less individual variability between 12 and 17 months of age.

These findings corroborate other studies that show that the course of development is characterized by intense variability in which periods of developmental quiescence or stability are followed by periods of high rates of acquisition, resulting in variability in intra-individual and inter-individual scores and between different domains of development. Contemporary researchers have reinforced the premise that variability, not linearity, is a characteristic of typical development ${ }^{19,20,23,24}$. These assumptions make it more difficult to correctly identify instances of delay or change in development. Darrah et al. ${ }^{19}$ examined intra-individual stability in the gross motor performance scores of typical infants during the first 18 months of life and found that the individual scores varied considerably, which made it impossible to identify a systematic pattern of changes among them. This finding corroborates the result of the present study, especially regarding fine motor skills for which there was great individual variability.

In 2003, Darrah et al. ${ }^{23}$ investigated the stability of scores in the areas of fine and gross motor development and communication in a longitudinal study on infants between 9 and 21 months of age. The authors found a high variability in intra-individual scores, between individuals and between the different areas studied. The authors emphasize that the development process is marked by a typical non-linearity, rather than at a constant rate, with little correlation between the gross and fine motor development, suggesting that these two motor areas are developed independently, contradicting the assumptions of ipsative or intra-individual stability.

Considering the challenge of the early diagnosis of abnormalities, Rosenbaum ${ }^{24}$ suggests that the identification of differences and variations in development should be interpreted with caution, keeping in mind that normal variations occur in early childhood and that there is always the possibility of monitoring the child's development rather than basing a decision on a single assessment. The concept of monitoring development was also emphasized in a study that followed the trajectory of the gross and fine motor development of a group of children from 9 months until 5 years of age ${ }^{20}$. The results of the study from Darrah, Senthilselvan and Magill-Evans ${ }^{20}$ support the hypothesis that the trajectory of acquisition of gross and fine motor skills is characterized by intra-individual variability and by fluctuation in their rate of emergence.

The difference between the motor domains of infants in the present study can also be justified by the low level of environmental stimulation or lack of opportunities to reach the developmental potential. The National Curriculum Reference for Children's Education ${ }^{17}$ points to evidence that, in many institutions, infants spend most of the day in their cribs, which limits the opportunities to explore the environment and interact with other children, with possible effects on motor skills.

A study conducted by Barros, Halpern and Menegon ${ }^{25}$ aimed to verify the operational practices of day care centers in aspects related to child care (health control, hygiene, and nutrition), organization (supervisors, training, minimum staff and child:staff ratio), and infrastructure (facilities and minimum areas, building standards). The results showed that the number of children in public day care centers was greater than the number of children in private ones, and that each employee is responsible for six children aged zero to two years. In the day care centers that took part in the present study, the child:staff ratio was 7:1, with groups of up to 14 children, sometimes reaching 15. Although in Brazil, the ratio in municipal day care centers is acceptable ${ }^{26}$, the National Center for Education in Maternal and Child Health ${ }^{27}$, in line with the American Public Health Association and the American Academy of Pediatrics, recommends that the child:staff ratio during the first year of life should be 3:1 with groups of up to six children and that, in the age group of 13-30 months, this ratio should be 4:1 with groups of up to eight children.

Other studies ${ }^{11,14,22}$ have also reported unfavorable conditions for motor development in children attending day care centers. De Barros et al. ${ }^{11}$ considered environmental risk factors 
for motor development in healthy children attending private or public day care centers. The authors pointed to a) the use of inappropriate toys for the children's age, b) the inadequacy of the places where the children were kept at a premature age, c) the lack of pedagogic supervision, d) premature extra-familial socialization, and e) low familial socioeconomic status. The results indicated that the development of biologically healthy children may be negatively influenced by environmental risk factors. In the study by Eickmann et al. ${ }^{22}$, the fall in development rates (after weekly iron supplementation) in children aged four to 24 months was attributed to the low level of stimulation received, resulting from poor socioeconomic and environmental conditions, in addition to long hours in day care with an insufficient number of caregivers. Maciel ${ }^{14}$ indicates that, in child care centers, work overload combined with a lack of knowledge about developmental stimulation techniques can affect the quality of psychosocial stimulation provided to children and, consequently, their mental and motor development.

Another result to be discussed in the present study was the identification of four infants with suspected delays in motor development when considering both assessments at 12 and 17 months of age. Although this result must be observed with caution due to the fact that there were only two assessments over the course of the study, it is important to emphasize that it stemmed from a diagnostic tool designed for assessing child development. Diagnostic tests are more expensive and time-consuming, however they are considered the gold standard for measuring developmental outcomes and providing objective, valid, and reliable measures of child development ${ }^{28}$. Therefore, this result is relevant in terms of prevention as it identified four (13\%) children with suspected delays in two repeated measures, and it showed the importance of developmental monitoring and follow-up as a strategy for identifying risk, which has been strongly recommended by the literature ${ }^{20,23,24}$.

It is worth noting that, for at least one of the four children with suspected delay in both assessments, the motor performance scores may have been influenced by preterm birth and low birth weight. Although the influence of neonatal risk factors in motor development is widely recognized, the present study did not find medical complications, and the preterm infants were evaluated according to their corrected age. There is evidence that, in the absence of clinical complications and with age correction for preterm infants, their motor development may be similar to that of full-term children ${ }^{29}$.

Rosenbaum $^{24}$ highlights at least two reasons that justify developmental monitoring. First, most developmental disorders manifest themselves over time, and second, the diagnosis of these disorders is based on the observation of phenomena or on a judgment of the child's history and evaluation. Darrah et al. ${ }^{23}$ point out that the combined results of repeated assessments may elucidate low scores by determining whether they represent a true delay or just a period of developmental quiescence.

Although the results for the motor performance of the group studied are not alarming, it is noteworthy that the motor domain with the poorest outcome (gross) also showed less variability from 12 to 17 months of age. For a reliable diagnosis of motor development, the presence of three conditions ${ }^{20}$ is recommended: a) unfavorable results in the assessment(s); b) expressions of concern by the family regarding the child's development (in this case, concerns on the part of the caregivers should also be considered); c) the rater's observation and clinical impression. Of the four children with suspected delays in both assessments, two of them met these three conditions, which together contribute to the identification of changes in development.

Overall, the present study suggests the need for greater attention to motor development during the first 17 months of life in infants attending public day care centers full time, with particular surveillance of gross motor development (considering that this is part of the child's overall development) and of children with suspected delays in motor performance in consecutive assessments. A clinical implication of this suggestion would be surveillance by specialists in early childhood education institutions, which would allow the analysis of the trajectory of development during the first months and years of life, the identification of children at risk of delay, and hence the establishment of intervention strategies to promote development. This implication is in line with the guidelines for the establishment of developmental surveillance outlined in the literature in the areas of pediatrics, physical therapy, and rehabilitation sciences ${ }^{20,23,24,28}$. The limitations of the present study were the short follow-up only until 17 months of age, the use of only two measures of motor performance, and the lack of investigation of the quality of care given to the children at the day care centers and in the household.

\section{Acknowledgements : :}

Fundo de Apoio à Pesquisa da UNIMEP/Protocol 369/05; Fundo de Apoio à Extensão da UNIMEP/Protocol 21/06; Bolsas de Iniciação Científica PIBIC/CNPq and FAPIC/UNIMEP; Núcleo de Estudos e Pesquisas em Pedagogia do Movimento - NUPEM/UNIMEP. 


\section{References $: \because 8$.}

1. Didonet V. Educação infantil: a creche um bom começo. INEP/MEC Instituto Nacional Estudos e Pesquisas Educacionais. 2001;18(73):1-161.

2. Belsky J. Early child care and early child development: Major findings of the NICHD study of early child care. Eur J Dev Psychol. 2006;3(1):95-110.

3. Sylva K, Melhuish E, Sammons P, Siraj-Blatchford I, Taggart B. The Effective Provision of PreSchool Education (EPPE) Project: Findings from Pre-school to end of Key Stage1. London: Institute of Education/DfES. 2004. Retrieved from http://www.dcsf.gov.uk/research/data/ uploadfiles/SSU_SF_2004_01.pdf.

4. Belsky J, Vandell DL, Burchinal M, Clarke-Stewart KA, McCartney K, Owen MT; NICHD Early Child Care Research Network. Are there long-term effects of early child care? Child Dev. 2007; 78(2):681-701.

5. Amorim KS, Rossetti-Ferreira MC. Análise crítica de investigações sobre doenças infecciosas respiratórias em crianças que freqüentam creche. J Pediatr. 1999;75(5):313-20.

6. Maranhão DG. 0 processo-saúde-doença e os cuidados com a saúde na perspectiva dos educadores infantis. Cad Saúde Publica. 2000;16(4):1143-8.

7. Veríssimo MLOR, Fonseca RMGS. 0 cuidado da criança segundo trabalhadoras de creches. Rev Lat Am Enferm. 2003;11(1):28-35.

8. Fisberg RM, Marchioni DML, Cardoso MRA. Estado nutricional e fatores associados ao déficit de crescimento de crianças freqüentadoras de creches públicas do município de São Paulo. Cad Saúde Publica. 2004;20(3):812-7.

9. Santos DCC, Tolocka RE, Carvalho J, Heringer LRC, Almeida CM, Miquelote AF. Desempenho motor grosso e sua associação com fatores neonatais, familiares e de exposição à creche em crianças até três anos de idade. Rev Bras Fisioter. 2009;13(2):173-9.

10. Paula CS. Atrasos de desenvolvimento mental e motor em crianças de creches de comunidade urbana de baixa renda e fatores de risco associados [dissertação]. São Paulo: UNIFESP; 2001.

11. De Barros KM, Fragoso AG, de Oliveira AL, Cabral Filho JE, de Castro RM. Do environmental influences alter motor abilities acquisition? A comparison among children from day-care centers and private schools. Arq Neuropsiquiatr. 2003;61(2A):170-5.

12. Souza SC. Avaliação do desenvolvimento neuropsicomotor do pré-escolar de creches públicas de Cuiabá-MT [dissertação]. São Paulo: Universidade de São Paulo; 2004.

13. Rezende MA, Beteli VC, dos Santos JL. Folow-up of the child's motor abilities in day- care centers and pre-schools. Rev Lat Am Enfermagem. 2005;13(5):619-25.

14. Maciel AMS. Desenvolvimento mental e motor de crianças em creches da rede municipal do Recife [dissertação]. Pernambuco: Universidade Federal de Pernambuco; 2006.

15. Biscegli TS, Polis LB, Santos LM, Vicentin M. Avaliação do estado nutricional e do desenvolvimento neuropsicomotor em crianças freqüentadoras de creche. Rev Paul Pediatr. 2007;25(4):337-42.
16. Sabatés AL, Mendes LCO. Perfil do crescimento e desenvolvimento de crianças entre 12 e 36 meses de idade que freqüentam uma creche municipal da cidade de Guarulhos. Ciênc Cuid Saúde. 2007;6(2):164-70.

17. Brasil. Ministério da Educação e do Desporto. Secretaria de Educação Fundamental. Referencia Curricular nacional para educação infantil/ Ministério da Educação e do Desporto, Secretaria de Educação Fundamental [Internet book]. Brasília: MEC/SEF; 1998. Retrieved on Nov 102007 from http://portal.mec.gov.br/seb/index.php?option= content\&task=view\&id=556.

18. Batista R. A rotina no dia-a-dia da creche: entre o proposto e o vivido [dissertação]. Florianópolis (SC): Universidade Federal de Santa Catarina; 1998.

19. Darrah J, Redfern L, Maguire TO, Beaulne AP, Watt J. Intra-individual stability of rate of gross motor development in full-term infants. Early Hum Dev. 1998;52(2):169-79.

20. Darrah J, Senthilselvan A, Magill-Evans J. Trajectories of serial motor scores of typically developing children: Implications for clinical decision making. Infant Behav Dev. 2009;32(1):72-8.

21. Bayley N. Bayley scales of infant and toddler development. Third Edition. San Antonio: Harcourt Assessment; 2006.

22. Eickmann SH, Brito CMM, Lira PIC, Lima MC. Efetividade da suplementação semanal com ferro sobre a concentração de hemoglobina, estado nutricional e o desenvolvimento de lactentes em creches do Recife, Pernambuco, Brasil. Cad Saúde Publica. 2008;24(Suppl 2):303-11.

23. Darrah J, Hodge M, Magill-Evans J, Kembhavi G. Stability of serial assessments of motor and communication abilities in typically developing infants: Implications for screening. Early Hum Dev. 2003;72(2):97-110.

24. Rosenbaum P. Classification of abnormal neurological outcome. Early Hum Dev. 2006;82(3): 167-71.

25. Barros AJD, Halpern R, Menegon OE. Creches públicas e privadas de Pelotas, RS: aderência à norma técnica. J Pediatr. 1998;74(5):397-403.

26. Vitória T, Rossetti-Ferreira MC. Processos de adaptação na creche. Cad Pesqui. 1993;86: $55-64$.

27. American Academy of Pediatrics, American Public Health Association, and National Resource Center for Health and Safety in Child Care and Early Education. Caring for Our Children: National Health and Safety Performance Standards: Guidelines for Out-of-Home Child Care Programs, 2nd edition. [Internet book]. Elk Grove Village, IL: American Academy of Pediatrics and Washington, DC: American Public Health Association; 2002. Retrieved Feb 102009 from http://nrc.uchsc.edu/ CFOC/ PDFVersion/list.html and http://nrc.uchsc.edu/CFOC/PDFVersion/Chapter\%201.pdf.

28. Johnson S, Marlow N. Developmental screen or developmental testing? Early Hum Dev. 2006; 82(3):173-83.

29. Mancini MC, Teixeira S, Araújo LG, Paixão ML, Magalhães LC, Coelho ZAC, et al. Estudo do desenvolvimento da função motora aos 8 e 12 meses de idade em crianças nascidas pré-termo e a termo. Arq Neuropsiquiatr. 2002;60(4):974-80. 